\title{
Előtagos és előtag nélküli vonatkozó névmások versengése a középmagyar kor első fél évszázadában*
}

1. Bevezetés: váltakozás, változás, regiszter. Néhány évtizeddel ezelőtt, a múlt század vége felé nyelvtörténészek arra a felismerésre kezdték alapozni kutatásaikat, hogy a nyelv változási folyamatai a szinkrón állapotbeli váltakozásokban gyökereznek (pl. BENKÖ 1988: 79, 107 és passim; KROCH 1989, 1994: 2-6). Azok a jelenségek, amelyek az adott nyelvállapotban egymás változatainak mutatkoznak, a következő nyelvállapot(ok) felől nézve a változási folyamatok kiindulópontját jelenthetik. Éppen ezért - ahogy KÁROLY SÁNDOR megfogalmazta - a történetinyelvtan-írás egyik feladata annak vizsgálata, hogy milyen eredményre vezet az egymás mellett élő megoldások, a régebbi és újabb formák nyelvtörténetet alakító versengése (KÁROLY 1980: 45).

A változók vizsgálata tehát a leíró szociolingvisztikán túllépve előbb-utóbb teret követelt magának a történeti grammatika kutatásában is. Központi szerephez jutott a nemzetközi színtéren ekkoriban kiformálódott tudományterületen, a történeti szociolingvisztikában, amely a nyelvtörténeti vizsgálatokra kezdte alkalmazni a leíró szociolingvisztika kérdésfeltevéseit és módszereit. Az új részdiszciplína azután a hazai kutatóközösségben is kibontakozásnak indult; szemléletmódját, alapkérdéseit az ezredfordulót követően már nyelvtörténeti tankönyv is ismertette (KISS 2003: 28-30, 37-41).

Nyelvi változás és váltakozás egymással többféleképpen is összefügg. A változásokban ugyanakkor nem mindenfajta váltakozás jut szerephez. A nyelvtörténet felől közelítve kétféle váltakozástípust tarthatunk számon. A történeti folyamatok szempontjából az instabil típus a meghatározó, a stabil váltakozásra ugyanis az jellemző, hogy a nyelvhasználók számára folyamatosan adott a változatok közötti választási lehetôség. Az instabil típusnak ezzel szemben felderítésre érdemes életrajza van (vö. PINTZUK 2003: 509-510). Létrejön: a nyelvhasználók váltakozó formákat kezdenek használni a nyelvi rendszer olyan pontján, ahol korábban nem volt opcionalitás; majd megszünik: a nyelvi változást eredményező váltakozás esetében az innovatív forma kiszorítja a konzervatívat, azaz a változási folyamat lezárultával ismét opciók nélküli helyzet áll elö. A lentebbiekben viszont azt is látni fogjuk, hogy amennyiben egy változás hosszan elnyúlik az időben, a két típust nem lehet mereven elkülöníteni egymástól.

A jelen tanulmány a címben megjelölt váltakozás életrajzának meghatározó szakaszába nyújt betekintést: a folyamatban lévő nyelvi változás terjedésének aktuális állapotát vizsgálja. Az innovatív (előtagos) változatok térnyerését mutatja be, figyelmet fordítva a terjedésében megmutatkozó nyelvi regiszterbeli különbségekre.

* A kutatás az NKFIH-OTKA által támogatott K 116217 sz. pályázat részét képezi (MTA NYTI, Magyar nyelvtörténeti kutatócsoport). 
Választ keres a kérdésre, hogy a középmagyar kor elején melyik regiszteré a vezető szerep a vizsgált újítás terjedésében. A beszéltnyelv(közel)i nyelvhasználaté, amely a nyelvi változások megindulásának elsődleges terepe? Vagy a könyvnyomtatás - szerzők és nyomdászok által gondosan kiformált - nyelvezete enged utat hamarabb az újításnak?

Mielött azonban a kérdések nyomába erednénk, tekintsük át röviden magát a témául választott jelenséget!

2. Vonatkozó névmások: történeti folyamatok, váltakozások. Mint az közismert, a vonatkozó névmások csoportja a különböző nyelvekben kétféle korábbi névmásból alakulhat ki. A forrás a mutató, illetve a kérdő névmás; vannak nyelvek, amelyekben a két grammatikalizációs lehetőségnek csak egyike vagy másika jutott érvényre, míg más nyelvekben mindkétféle származású elem jelen van. A gyakoribb forráselem a mutató névmás; a folyamat tipikus grammatikalizációs ösvényt követ, amennyiben a referencia a térbeliről a szövegbelire tevődik át. Ugyanakkor a kérdő névmás is számos nyelv relatívumainak forrása. (Vö. BuDENZ 1866: 20; HEINE-KUTEVA 2002: 113-115.) A magyar aki, ami, amely stb. elemek az utóbbi csoportba tartoznak: alapvetően kérdő névmásformákra mennek vissza. Megjegyzendő, hogy a ki, mi, mely stb. típusú kérdő névmások az ősforrások, közvetlen előzménykategóriaként azonban nem ezek, hanem a belölük kialakult határozatlan névmások szolgálnak (1. pl. JuHÁsz 1991: 478; SIPOS 1991: 390).

A magyar nyelvtörténet folyamán hosszasan zajlik a relatívum alaki elkülönülése a forrásául szolgáló névmáskategóriától. Vonatkozó névmásként a mai magyarban többnyire az $a(z)$ - előtagos változatok használatosak, korábbi korokból származó - akár csak egy évszázaddal ezelötti - szövegekben azonban szembeötlö, milyen sokáig tartották magukat az előtag nélküli formák is. Mára az előtag nélküli $k i, m i$ kikopott a szóbeliségből, az írásbeliségben való igen ritka megjelenése pedig a felstilizáltság és/vagy a régiesség árnyalatát hordozza. A mely amely váltakozás némileg más mintázatot követ: itt az előtag nélküli forma - föként az írásbeliségben - viszonylag gyakrabban használatos. ${ }^{1}$ De másfajta vonatkozó névmási váltakozások is említhetők a mai nyelvhasználatból éppúgy (pl. a könyv + amely $\sim$ ami), ahogyan régebbi korokból is (pl. a könyv $+k i \sim$ mely).

Az ó- és középmagyar korszakban a relatívumok körében kétféle látványos versengés is megfigyelhetö. Egyrészt versenyeztek egymással a különböző névmások, elsősorban a [- személy] jelentésjegyü alaptagok melletti pozícióért $(\mathrm{ki} / \mathrm{mely}$ $\sim m i$ stb.). Másrészt pedig - mindegyik névmás esetében - konkurált egymással a régebbi, előtag nélküli és az újabb, előtagos alakváltozat is. Az előbbi váltakozást egy közelmúltban megjelent tanulmányomban vizsgáltam, középpontba állítva a középmagyar kori magánélet(közel)i nyelvhasználatot (DÖMÖTÖR 2017). A jelen dolgozat az utóbb említett váltakozást tárgyalja, az ómagyar kori előzményekre

${ }^{1}$ A nyelvhasználati megfigyelést alátámasztják az MNSZ. adatai: az adattár szerint 1 millió szövegszóra átlagosan 2639 amely és 728 mely jut. Az előtag nélküli változat 728-as elemszáma azonban tovább pontosítandó, mivel ebben a kérdő névmási mely alakok is benne foglaltatnak. Ez utóbbiak - szüréspróbám szerint - az adatnak hozzávetőleg a 10\%-át teszik ki. Ennek alapján a vonatkozó névmási amely/mely átlagos megjelenése 1 millió szövegszóként 2639/kb. 655-ben állapítható meg. 
való kitekintéssel a középmagyar korszak elejének többféle regiszterében is. A vizsgálat a $k i \sim a(z) k i, m i \sim a(z) m i$, mely $\sim a(z)$ mely párokra terjed ki, más vonatkozó névmások az érintett korszakokban nem szerepelnek meggyőző számban. ${ }^{2}$

2.1. Az előtagos változatok megjelenése a rendszerben. Az $a(z)$ - előtaggal szerkesztett vonatkozó névmási formák egymásra épülő grammatikalizációs folyamatok során keletkeztek, amelyekből váltakozások és változások rendszere rajzolódik ki.

Elsőként az előtag nélküli változatok jöttek létre a fentebb már említett kérdő névmás $>$ határozatlan névmás > vonatkozó névmás folyamat újraelemzése során. Ez a változási sor még az ómagyar korszakot megelőzően lezajlott, hiszen a legkorábbról fennmaradt szövegemlékekben azt láthatjuk, hogy közülük mindazok, amelyekben egyáltalán előfordulnak alárendelő összetett mondatok (HB. és HBK., KT. és KTSz., ÓMS.), tartalmaznak vonatkozó mellékmondatokat is, élükön határozatlan-vonatkozó komplex, illetve tisztán vonatkozó névmással.

Formáját tekintve tehát a relatívum eleinte nem különült el forrásszófajától. Amirôl a korai ómagyar adatok még nem vallanak (talán csak a kis elemszám miatt), arra a kései ómagyar kor legeleje (JókK.) már bizonyságot szolgáltat: ha ritkaságként is, de megmutatkoznak az a(z)- elötagos változatok is. Folyamatban van tehát a vonatkozó névmás alaki elkülönülése, egyben előállt a vonatkozó névmási változó két változata. ${ }^{3} \mathrm{Az}$ előtagos formák a mutató névmás és a vonatkozó névmás fúziójával jöttek létre olyan mondatszerkezetek újraelemzésével, amelyekben a főmondat alanyi szerepü utalószava és az alárendelt tagmondat élén álló relatívum közvetlenül szomszédosak voltak (1. pl. G. VARGA 1992: 525-528; JUHÁSZ 1992: 791-792; HAADER 1995: 517-518, 540). Ez a feltétel többféle tagmondatelrendezés esetén is megvalósulhatott: Eljött az, kit vártunk $\rightarrow$ Eljött, azkit vártunk; Az, kit vártunk, eljött $\rightarrow$ Azkit vártunk, eljött. Az újraelemzés alapjául az a váltakozás szolgált, amely a szerkezettípusban lehetővé teszi az utalószó kitételét és ki nem tételét is. Ha ugyanis egyaránt lehetséges felállás az Eljött, kit vártunk és az Eljött az, kit vártunk is, az utalószó a szerkezet grammatikalitásának sérelme nélkül kimozdulhat eredeti szerepéből. Minthogy az összetett mondatok kapcsolatában a veláris hangrendü mutató névmás meghatározó nagyságrendekkel gyakoribb, mint a palatális hangrendủ, előtagként is ez a forma szilárdult meg. Az ómagyarban ugyanakkor szórványosan még előfordul $e(z)$ - elötag is (G. VARGA 1992: 525).

Bár ezen a ponton eljutottunk a jelen vizsgálat kiinduló állapotához - felállt az innovatív (előtagos) és a konzervatív (elötag nélküli) változatok versenyhelyzete -, a fentiekkel kapcsolatban még idekívánkozik egy tipológiai természetü megállapítás. A szokásos kategorizálást érdemes árnyalni: tény, hogy a magyarban a vonatkozó névmás alapvető forrásszófaja a kérdő névmás, azonban számon kell tartani, hogy a későbbiekben a mutató névmás is forrásszófajként lépett be a rend-

${ }^{2}$ A dolgozatban egységesen $a(z)$ - formával jelölöm az előtagos alak különböző korábbi ejtés-, illetve írásváltozatait (egybe- vagy különírt $a k i \sim a z k i \sim a$ 'ki akki).

${ }^{3}$ A határozatlan névmás vala- és né- előtagos alakjainak elterjedése, vagyis ennek a kategóriának a formai elkülönülése ekkor már jóval előrébb tartott. 
szerbe. Hasonló újraelemzés zajlott le, mint azokban a nyelvekben, amelyekben a mutató névmás (is) forráskategóriaként szolgált (kézenfekvő például az angol that-re gondolni). Lényeges eltérés ugyanakkor, hogy a mutató névmás a magyarban nem önmagában elemződött újra - ennek megfelelően önállóan nem is töltheti be a vonatkozó névmás szerepét -, hanem a vonatkozó névmás korábbi formájával kombinálódva került bele a rendszerbe.

2.2. Lassú terjedés, szabad váltakozás. A vonatkozó névmások előtagos változatainak használata az egész ómagyar korszak folyamán szük körü. (Számos esetben pedig - elsősorban helyesírási és központozási fogódzók híján - nem lehet megállapítani, hogy még a forrásszerkezettel, vagy pedig már az új alakulattal állunk-e szemben.) A terjedés a középmagyar kor előrehaladtával egyre számottevőbb lesz - erről a lentebbiekben még sok szó fog esni. Az előtagos változatok térnyerését a legszemléletesebben a bibliafordításokból vett párhuzamos helyekkel lehet bemutatni - elöljáróban tehát álljon itt két adatsor, amely a kései ómagyar és a korai középmagyar fordítók megoldásaiba nyújt betekintést. ${ }^{4} \mathrm{Mk}$. 14,70: $k i$ k ott állnak vala, mondanak (MünchK. 52ra); $k i k$ állonak vala, mondnak (DöbrK. $225 \mathrm{r}-\mathrm{v}) ; \mathrm{k} i \mathrm{k}$ vele állnak vala, mondanak (JordK. 112ra); a kik ott állanak vala, mondnak vala (Pesthi 105b); a zkik ott állanak vala, ezt mondják vala (Sylvester 1: 75a); a kik ott állnak vala, Pétörnek mondának (Heltai 105a); a kik ott állanak vala, mondának (Károlyi 2: 74a). Mk. 14,21: az embernek, $k i$ miatt (MünchK. ); az embernek, $k i$ miá (DöbrK. 223r); az embernek, ki nek miatta (JordK. 111rb); az embernek, $k i$ által (Pesthi 103a); az embernek, a z ki miatt (Sylvester 73a); az embernek, a ki által (Heltai 102b); az embernek, a z kiáltal (Félegyházi 78b); az embernek, a z ki által (Károlyi 2: 45b).

A terjedési folyamat a vizsgált korszakban messze nem zárul le, amit a leginkább szembetünően az is mutat, hogy - amint fentebb már szóba került - a mely amely a mai napig élő változatok. Véleményem szerint a 7-8 évszázada tartó folyamat az instabil és stabil váltakozás egymásba való átmenetét példázza. ${ }^{5} \mathrm{~A}$ mely amely instabil váltakozás nem az innovatív forma kizárólagosságközeli győzelmével zárult, hanem beállt egyfajta stabil váltakozás - már amennyiben a mai állapotot ilyennek lehet tekinteni. (Hogy valóban lehet-e, az viszont a jelenség jövőbeli alakulásának kérdése. A mai nyelvhasználat alapján egyébként arra is látszik esély, hogy előbb-utóbb a változó mindkét változatát ki fogja szorítani az ami névmás.)

Ahogy ma saját nyelvhasználati szokásainkon alapul a döntés, hogy egy vonatkozó mellékmondat élére a mely-t vagy az amely-t írjuk, korábbi korokban mindhárom névmáspárban szabadon váltakozhattak az előtagos és az előtag nélküli formák. Ez a variabilitás a vizsgált korszak szerzőinél, magánéleti nyelvhasználóiánál is tetten érhetö.

${ }^{4}$ Tanulmányomban a nyelvi adatokat az olvasat szerinti átírásukban közlöm. A forrásokat a dolgozat végén adom meg.

${ }^{5}$ A rendkívül hosszasan zajló terjedési folyamat egy elméleti kérdéssel is szembesít: a modellezésre széles körben elfogadott S-görbe felső tartományának mennyire kell megközelítenie a 100\%-ot, hogy az innovatív forma elterjedése komplettnek legyen mondható? Vagyis: mikortól tekinthető befejezettnek a nyelvi változás? (Ennek ténye nem mosható össze a szabályváltozás terjedésének fogalmával; vö. pl. JOSEPH 2012.) 
Kiválóan példázzák az ad hoc jellegü váltakozást a következő adatpárok, amelyek Károlyi Gáspár munkájából, a Két könyv...-ből származnak. Az első példapárban ugyanaz a mondat szerepel; először bibliai idézetként, azután (hat mondaton belüli szövegkörnyezetben) a bibliai szöveghely magyarázatának részeként: Emberek megszáradnak az félelemnek miatta és azoknak várásának miatta, a z m e ly e k következnek ez világra Továbbá azt mondja, hogy az emberek megszáradnak az félelemnek miatta és azoknak várásoknak miatta, me ly e $k$ következnek (M1a, M1b). A második adatpár szintén közeli (három mondaton belüli) szövegkörnyezetből származó mondatokat tartalmaz, amelyek tökéletesen azonos szerkezetüek: Bódogok, kik öbenne biznak Bódogok, a z kik hallgatják az Istennek igéjét, és megtartják azt (C1b, C2a). A harmadik példapár is (az utalószó számvonatkozásától eltekintve) azonos szerkezetủ párhuzamot mutat, öt mondaton belüli szövegkörnyezetben: Jaj annak, a z ki az ö házát épiti hamissággal Jaj azoknak, ki k álnokságot gondolnak az ö ágyasházokban (G4b, G5a).

A névmásformák váltogatása nem feltétlenül véletlenszerü minden esetben; állhat mögötte a szövegezés változatosságára való törekvés, illetve a többszörös vonatkozó kapcsolatok követésének megkönnyítése (?): Nem annak, m e ly a törvényböl vagyon csak, de annak is, a me ly Ábrahámnak hitiböl vagyon (Telegdi: Felelet 47); Ez levelet irja Szent Pál az galatiabelieknek, m ely ne k ugyanazon értelme vagyon, a z me ly az rómabelieknek irt levélnek (Sylvester: Újszövetség 54a); Nem arra való tanácsot adsz nekem, $k i$ én hasznomra volna, hanem a $k i$ az te megéhezett hasad töltére (Pesthi: Fabulák 41a).

További vizsgálat nyomán feltárható, hogy bizonyos fajta szerkezetekben lehet-e szignifikánsan gyakoribb egyik vagy másik megoldás (például az utalószó jelenlétével, illetve kitehetőségével vagy a tagmondatsorrenddel összefüggésben), az azonban bizonyos, hogy szigorú következetességre utaló használatbeli megfontolások még a legtudatosabb szövegalkotóknál sem érhetők tetten.

A korabeli és a korszakhoz közeli grammatikaírók (1539-ben SYLVESTER JÁNOS és 1610-ben SZENCZI MOLNÁR ALBERT) nem foglalkoznak a kérdéssel. SZENCZI annak ellenére jár el így, hogy olyan szempontot is érint, ahol kifejezetten helye volna az előtagos változatok említésének ( $k i$ típusú névmásösszetételek: SZENCZI 1610: 66; vö. C. VLADÁR 2004: 156). Úgy tünik, mintha az előtagot még önálló szóként kezelné (minden esetben külön is írja). Bizonyos példái alapján a mutató névmást, a névelőt és a vonatkozó névmási előtagot (?) ugyanazon elem különböző megvalósulásaiként állítja elénk (SZENCZI 1610: 161; vö. C. VLADÁR 2004: 350). Példaanyagából bizonyos preferenciák leszürhetők ugyan (előtagos változat használata nem jelzői szerepú mutató névmási utalószó vagy fordított mondatrend függvényében), a bemutatott mondatokban azonban váltakozás is megfigyelhetö (ez az ember, azkit; ez az jószág, melyet: SZENCZI 1610: 167; vö. C. VLADÁR 2004: 362).

3. A vizsgálat anyaga. Kutatásomhoz a középmagyar kor első évtizedeiböl - kb. 50 évének anyagából - gyüjtöttem adatokat. A pontos időkör: 1536-1591, amelynek határait az anyaggyüjtésbe bevont nyomtatott müvek megjelenési évei jelölték ki. 
A magyar nyelvű könyvnyomtatás első évtizedeiben megjelent müvekből összeállított korpuszom anyagát a lentebbiekben k ön y v yelvi regiszternek nevezem. A korszak nyolc kiemelkedő szerzőjének szépirodalmi, értekező, hitvitázó, elmélkedő és imádságszövegeit gyüjtöttem össze, összesen 860 ezer karakter (szerzőnként 70 ezer - 130 ezer karakter) terjedelemben. Bibliafordításokat és verses mủveket ez a korpusz nem tartalmaz; előbbieket azért, mert anyagukat önálló csoportnak tartottam fenn, utóbbiakat pedig azért, mert a vonatkozó névmási előtag megjelenését vagy elhagyását strófaszerkesztési okok is erősen befolyásolhatják.

Külön vizsgáltam meg tehát a korszakban megjelent öt biblia fordít á s t, mindegyikből a Márk-evangélium szövegét választva (amelynek terjedelme egyenként kb. 80 ezer, együttvéve tehát kb. 400 ezer karakter). A Bibliákat azért különítettem el az általános könyvnyelvi szövegcsoporttól, mert korábbi vizsgálataim alapján azt valószínüsítettem, hogy nyelvezetük - a fordítók kimagasló nyelvi tudatosságával összefüggésben - eltérhet más múfajokétól.

Az élönyelvi regiszter tanulmányozásához a Történeti magánéleti korpuszból (TMK.) vettem egy véletlenszerü mintát (828 adattal). Ennek anyaga olyan szövegtípusokból származik, amelyek a leginkább megközelítik a magánéleti nyelvhasználatot: bírósági tárgyalások leirataiból (zömmel tanúvallomásokból) és magánlevelekből. Olyan korokból, amelyekből hangzó anyag híján a beszéltnyelv közvetlenül nem tanulmányozható, ezek a szövegtípusok azok, amelyek a leginkább megközelítik a beszélők mindennapi nyelvhasználatát. (Az egyszerüség kedvéért élőnyelvinek vagy beszéltnyelvinek jelölöm a valójában csak élőnyelvközelinek mondható regisztert.)

4. Az elözmények: az előtagos formák a kései ómagyarban. A fentebb említettek értelmében ez az első vizsgálható korszak. Az 1-4. ábra G. VARGA GYÖRGYI adatsorai alapján készült (1992: 528). Az összadatszám 758, ennek csekély része képviseli az előtagos változatot (1. ábra).

1. ábra

Összkép a kései ómagyar korban

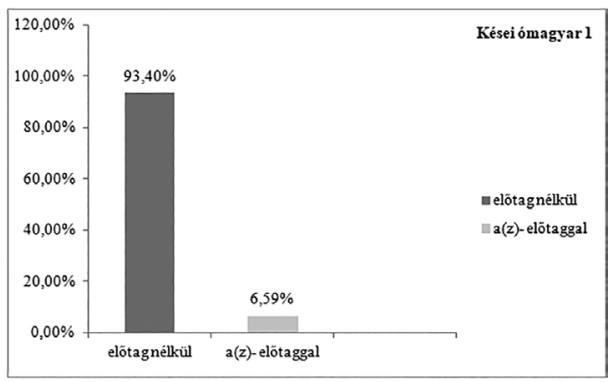

2. ábra

A $k i \sim a(z) k i$ a kései ómagyarban

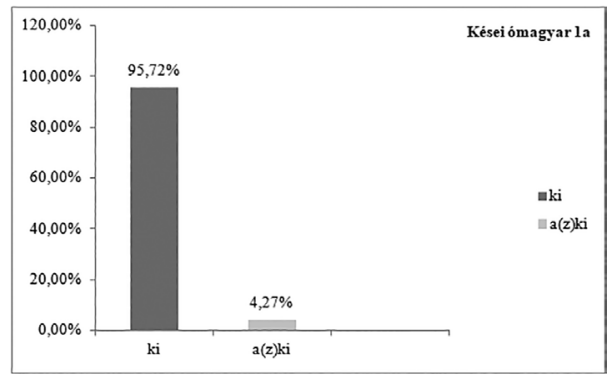

Ha névmástípusonként nézzük meg a váltakozásokat, azt látjuk, hogy a messze leggyakoribb ki-típus (655 előfordulás) és a lényegesen ritkább mely-típus (65 előfordulás) körében meglehetősen hasonló a konzervatív és az innovatív ala- 
kok aránya (2. és 3. ábra). Az ekkoriban terjedésnek induló mi-típus (38 előfordulás) viszont egészen más képet mutat, amennyiben itt máris az újabb változat részesedése a nagyobb (4. ábra). A tendencia tekintetében különösen figyelemre méltók az eredeti magyar nyelvü fogalmazványok (vö. G. VARGA 1992: 528), illetve a 15. századi fordítási piszkozatában fennmaradt Guary-kódex szövegalkotójának eljárásai (HAADER 1997: 119-122). A jelenség magyarázatát a hólabdaeffektus elvében kereshetjük (AITCHISON 1987: 29), amely szerint bizonyos esetekben különböző grammatikai szabályok együttműködve, egymást felerősítve váltanak ki valamilyen hatást. A középmagyar kori adatok alapján még egyértelmübbnek látszik a folyamat: a $m i$ vonatkozó névmás terjedése éppúgy később vesz lendületet a ki-hez és a mely-hez képest (DÖмÖTÖR 2008: 45, 46, 2017: 45-48), ahogyan a névmások előtagos változatai is az előtag nélküliekhez képest. A két újabban terjedő jelenség összekapaszkodik: a mi-t kevésbé köti a konvenció, mint régebbről származó és előtag nélkül megszokott társait, ezért hamarabb nyit az új forma irányába.

3. ábra

A mely $\sim a(z) m e l y$ a kései ómagyarban

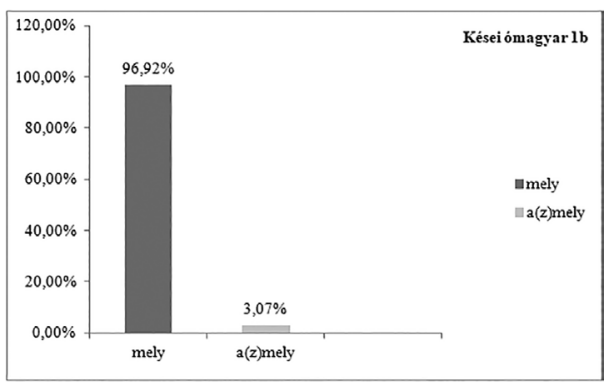

4. ábra

A $m i \sim a(z) m i$ a kései ómagyarban

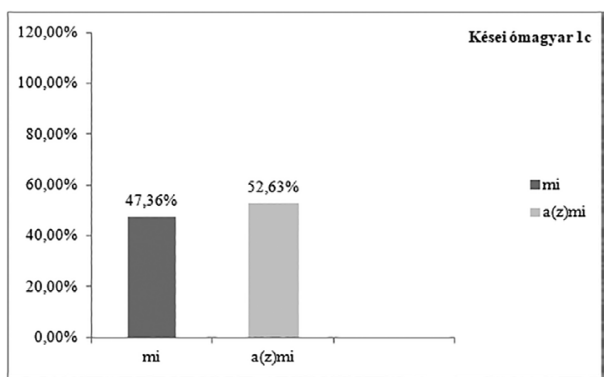

5. Az elötagos formák terjedése a vizsgált korszakban. Elsőként a könyvnyelvi regisztert, ezt követően pedig a bibliafordítások nyelvezetét veszem szemügyre - a kései ómagyar kori kódexirodalom regiszterbeli folytatásaként ezek a források kívánkoznak az élre. Utánuk kerül sor a beszéltnyelvi regiszterből származó adatok tanúságtételére.

5.1. A könyvnyelv jellemzői. Az 5-8. ábra a középmagyar kor első fél évszázadában nyomtatott könyvekre vonatkozóan mutatja az elötagos formák terjedését. A diagramok segítségével az adatok összevethetők az előző korszakkal. Az összadatszám 2058, ennek arányaiban bő háromszor akkora része képviseli az innovatív változatot, mint a kései ómagyarra vonatkozóan láttuk. A szignifikancia nagyon erős, a khí-négyzet próba eredménye: $p<0,001$. (5. ábra; vö. 1. ábra.) 


\section{5. ábra}

Összkép a vizsgált korszak könyvnyelvében

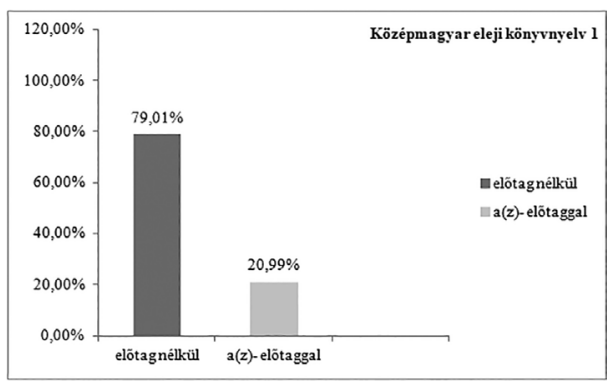

\section{6. ábra}

A $k i \sim a(z) k i$ a vizsgált korszak könyvnyelvében

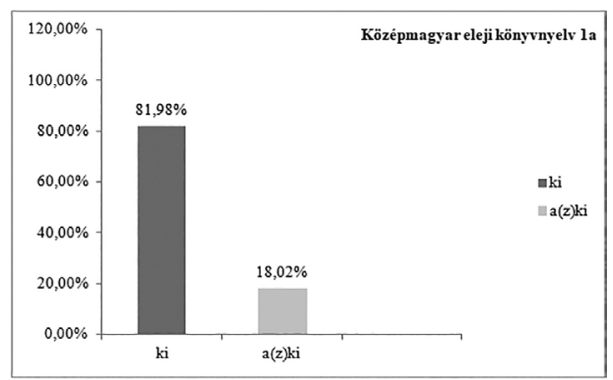

Az összképet erősen meghatározza az itt is messze leggyakoribb névmáspár, a ki a $\sim$ (z) ki gyakorisága (1204 előfordulás); amelyben az előtagos változat képviselete bő négyszeresére növekedett a kései ómagyarhoz képest. A szignifikancia itt is nagyon erös: $p<0,001$. (6. ábra; vö. 2. ábra.)

A mely a(z)mely esetében (662 előfordulás) kisebb, de azért látható az elmozdulás az előző korszakhoz képest. (7. ábra; vö. 3. ábra.) (Khí-négyzet próba itt nem végezhető, mert az egyik cellában $n<5$.) Ezen változó esetében egy egyelőre titokzatos történet elején vagyunk, hiszen éppen ez az a vonatkozó névmáspár, amelynek az előtag nélküli változata a mai napig részét képezi legalábbis az írásos nyelvhasználatnak. Már a 16. században azt lehet tehát tapasztalni, hogy a könyvnyelvben konzervatív változat lényegesen erősebben tartja magát, mint a másik két névmáspár esetében.

7. ábra

A mely $\sim a(z) m e l y$ a vizsgált korszak könyvnyelvében

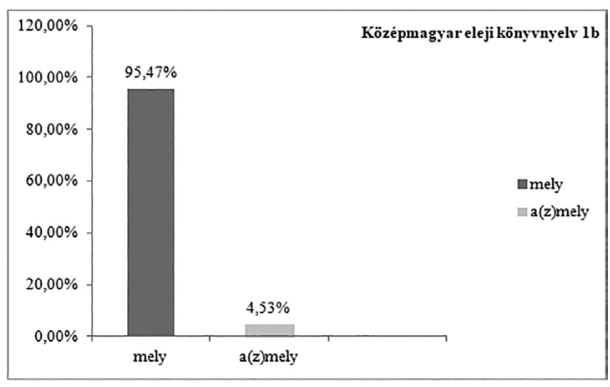

\section{8. ábra}

A $m i \sim a(z) m i$ a vizsgált korszak könyvnyelvében

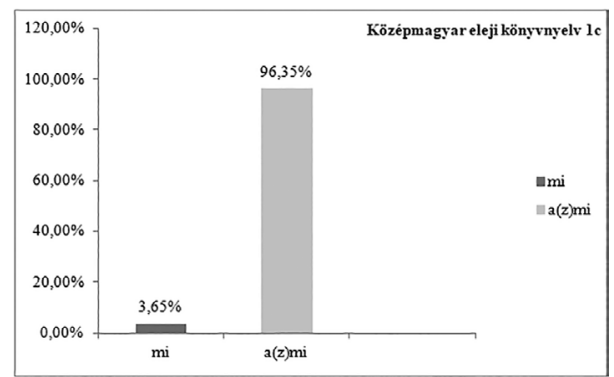

A $m i \sim a(z) m i$ névmáspárnál (192 előfordulás) az előtagos forma részvétele közel kétszeres növekedést mutat a kései ómagyarhoz képest. A szignifikancia nagyon erős: $\mathrm{p}<0,001$. (8. ábra; vö. 4. ábra.) A fentebb említett metaforánál maradva: a hógolyó, miután nekiiramodott a domboldalon, máris lavinává nőtt. Ezen névmáspár esetében a könyvnyelv az előtagos változatnak a 100\%-ot megközelítő 
értékével az elterjedést szinte komplettnek, ezzel pedig a nyelvi változást lényegében lefutottnak mutatja.

5.1.1. A bibliafordítások tanúsága. A megvizsgált öt Márk-evangéliumfordítás igazolta azt a várakozást, hogy a bibliafordítók nyelvhasználata eltérőnek mutatkozik az általános könyvnyelvi nyelvhasználattól. Az alkorpusz összesen 1013 adatot tartalmaz, amelyek körében a konzervatív és innovatív formák aránya csaknem fele-fele megoszlású. Az előtagos változatok részesedése közel két és félszerese az általános könyvnyelvi regiszter fentebb látott értékének. A szignifikancia nagyon erős: $\mathrm{p}<0,001$. (9. ábra; vö. 5. ábra.)

\section{9. ábra}

A korszak öt bibliafordításából kirajzolódó összkép

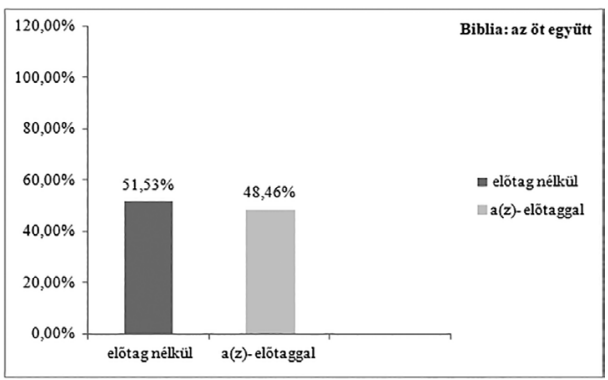

Az anyag számos tanulságot rejt névmások és szerzők szerinti bontásban is; ezek részletezésével nemrégiben másutt foglalkoztam (DÖMÖTÖR 2020). Két megfigyelést azonban mindenképpen szeretnék itt is kiemelni.

Az egyik, hogy az előtagos formák aránya még a legkevésbé újítónak mutatkozó névmáshasználatú szerzőnél is jelentősen magasabb, mint az általános könyvnyelvi regiszterben; a leginkább innovatív szerző pedig a könyvnyelvi értéknek több mint a négyszeresét produkálja (Pesthi Gábor, illetve Félegyházi Tamás).

A másik kiemelni való, hogy a névmáspárok szerinti bontás a könyvnyelvből megismert tendenciákhoz való hasonlóságokat és különbségeket is mutat. A ki-típusban az előtagos formák gyakorisága - a fele arányt megközelítő részesedéssel sokkal jelentősebb. A mely-típusban is lényegesen nagyobb az előtagos formák gyakorisága, a részesedés bő egyharmadnyi. A bibliafordításokban tehát kisebb a szakadék az $a(z) k i$ és az $a(z) m e l y$ előfordulási arányai között. Ennek ellenére a három névmáspár közül itt is a mely-típusban a leggyengébb az előtagos változat képviselete. A mi-típusban nincsen számottevő eltérés az általános könyvnyelvi adathoz képest; az előtagos változat teljességet megközelítő ( $96 \%$ fölötti) részesedése tehát a könyvnyomtatásban mutatkozik.

5.2. Az élőnyelv vallomása. A 10-13. ábra a középmagyar kor elejének beszéltnyelvében mutatja a vizsgált jelenség terjedését. A diagramok segítségével az adatok összevethetők a korszak könyvnyelvi regiszterében látott arányokkal, illetve az összkép a bibliafordítások jellemzésével is. Az összadatszám 828, ebből arányaiban hasonló nagyságú rész képviseli az előtagos változatot, mint a könyv- 
nyelvi regiszterben. Az eltérés nem szignifikáns: $p>0,50$. (10. ábra; vö. 5. ábra). A két mutató tehát a vizsgált szempontból egyszerre láttatja újításra kevésbé hajlamosnak az átalános könyvnyelvet és az élőnyelvet, mint a bibliafordítások nyelvhasználatát (vö. 9. ábra).

\section{0. ábra}

Összkép a vizsgált korszak élőnyelvében

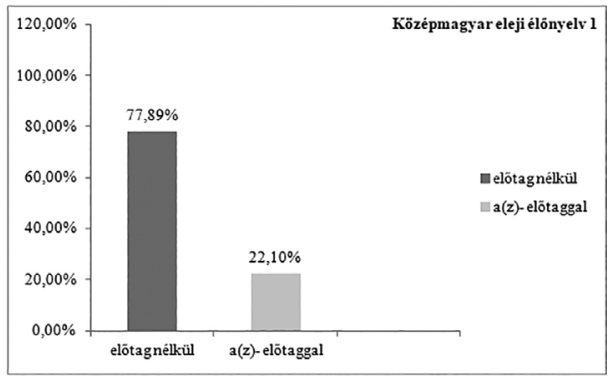

11. ábra

A $k i \sim a(z) k i$ a vizsgált korszak élónyelvében

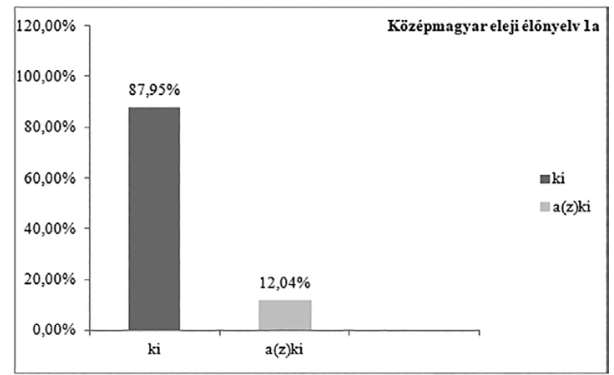

A névmáspárok szerinti bontás azonban jelentős különbségeket tár fel. A $k i$ $a(z) k i$ változatok (598 előfordulás) használati megoszlásában az élőnyelv konzervatívabbnak mutatkozik a könyvnyelvnél. Az előtagos változat részesedése az élőnyelvi regiszterben csak kétharmada a könyvnyelvben tapasztalt előfordulási aránynak; az eltérés erősen szignifikáns: $\mathrm{p}<0,01$. (11. ábra; vö. 6. ábra.)

A mely a(z)mely esetében (134 adat) éppen ellenkező a helyzet: itt az élönyelv mutatkozik jelentősen innovatívabbnak. Az előtagos változat megjelenési aránya több mint négyszerese a könyvnyelvi regiszterben látottnak. A szignifikancia nagyon erős: $p<0,001$. (12. ábra; vö. 7. ábra.)

\section{2. ábra}

A mely $\sim a(z)$ mely a vizsgált korszak élőnyelvében

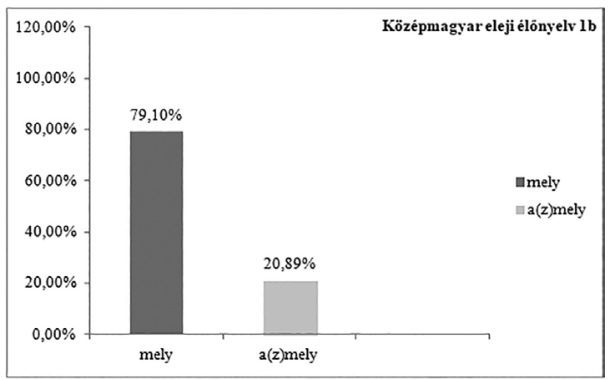

13. ábra

A $m i \sim a(z) m i$ a vizsgált korszak élőnyelvében

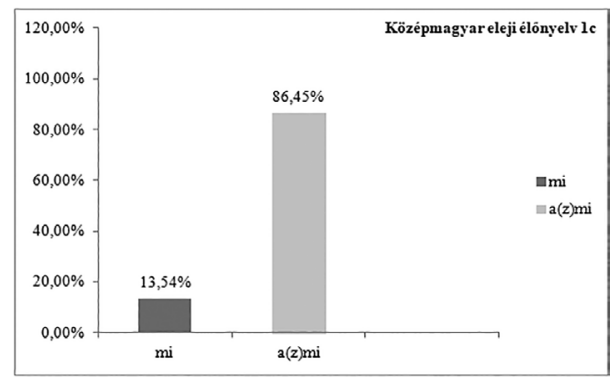

A $m i \sim a(z) m i$ névmáspárnál (96 előfordulás) a már megismert tendenciát látjuk az élőnyelvben is, azonban jóval visszafogottabb terjedéssel. Az eltérés erősen szignifikáns: $p<0,01$. Itt tehát az élőnyelvi regiszter ismét konzervatívabbnak mutatkozik a könyvnyelvinél. (13. ábra; vö. 8. ábra.) 
6. A vizsgált korszak összefoglaló jellemzése. Problémák és további feladatok. A tanulmányban a vonatkozó névmások előtagos és előtag nélküli formáinak váltakozását, az előtagos alakok terjedését összesen mintegy 4000 adatot vallatóra fogva mutattam be. (Pontos adatszám: 3899.)

Az előző korszakhoz viszonyított elmozdulást pusztán a nyelvtörténeti folyamatok szempontjából úgy is meg lehet ragadni, hogy a felhasznált forrásokat egyetlen közös korpuszként kezelve végezzük el a szinkrón állapotok összehasonlítását. Amennyire régebbi korok nyelvhasználata egyáltalán megismerhető, az ilyen, az adott korszak egészére jellemző adatnak is megvan a fontossága a változások tanulmányozásában.

A részkorpuszok külön-külön való vizsgálata azonban rétegzettebb betekintési lehetőséget kínál a vizsgált folyamatokba. A középmagyar kor elején megindul a magyar nyelvü könyvnyomtatás, a maga változatos müfajaival. Az anyanyelvü magánlevelezés, valamint a bírósági jegyzőkönyvezés is ekkorra válik viszonylag szélesebb körüvé. Az így tanulmányozható többféle nyelvhasználati réteg a történeti szociolingvisztika vizsgálati szempontjait is kiköveteli. A könyvnyelvi és az élőnyelvi regiszter különválasztásával nemcsak a terjedés tényéről tehetők megállapítások, hanem azt is vizsgálni lehet, melyik nyelvi réteg enged utat hamarabb az újdonságoknak.

A regiszterenként való vizsgálat ugyanakkor megszüntetni nem, legfeljebb bizonyos tekintetben tompítani képes a nyelvtörténeti anyag megragadását érintő anomáliákat. Az alapprobléma a reprezentációt - a valósághüséget és az arányosságot érinti: mennyiben tükrözheti bármely korpusz is az adott korszak élö, hiteles nyelvi viszonyait? Hiszen például a vizsgált korban a legtöbbféle szöveg a könyvkiadás produktumaiból ismerhető meg, holott ezekkel csak szükebb kör került kapcsolatba, ugyanakkor a spontán beszédesemények, amelyekben a nyelvi közösség minden tagja érintett, nem tanulmányozhatók közvetlenül; ráadásul a kiadott müvek nyelvezetét sokban meghatározzák az egyes müfajok sajátosságai (vö. LEHMANN 2004: 26-27; FAARLUND 1990: 18). A magánlevelekből, tanúvallomásokból vizsgálható beszéltnyelvközeli regiszter ugyancsak különféle tényezők befolyása alatt áll, mivel szintén az írásbeliség szüröjén keresztül hozzáférhetö, amely nem lehet mentes müfaji, illetve a lejegyzés tényéből fakadó befolyásoló tényezőktől. Mindezeken kívül megragadhatatlan az egyes regiszterek, müfajok hatásbeli különbsége a nyelvi folyamatok terjedésére (noha világos, hogy a skála egyik végén a templomi igehirdetéssel viszonylag nagy publicitáshoz jutó bibliafordítások, a másikon pedig például a perekben tanúvallomást tévő beszélők állnak). Reális viszonyítási alap ugyanakkor az alkorpuszok nagyságának mégoly gondos mérlegelésével sem adható meg: nyelvhasználati jelenségek esetében nyilvánvalóan nem lehet meghatározni alapsokaságokat (értelmetlen kérdés, hogy típusonként összesen hány vonatkozó névmást produkálhattak a nyelvhasználók az adott korban). A források kiválasztása és a nyelvi minta nagysága tehát - a korszakra vonatkozó gigakorpuszt kényszerủen nélkülözve - mindenképpen magán viseli az esetlegesség jegyeit.

Ami viszont mindezen esetlegesség tudatában is egyértelmủen megállapítható: a korszakban mind a három névmáspár körében a könyvnyelvi és az élönyelvi regiszterben is lendületet vesz az újabb változat terjedése. A vizsgált korra 
jellemző arányok az összes esetben azt jelezték, hogy az előtagos formák - jobban vagy kevésbé - megszaporodtak az ómagyar korhoz képest. Hogy ebben a könyvnyelvi vagy az élőnyelvi regiszteré-e a vezető szerep, első ránézésre nem mutatkozik meg. (Ellentétben például a korszak másik vonatkozó névmási váltakozásával, amellyel kapcsolatban korábban az bizonyosodott be, hogy az innováció terjedésében - a [-személy] antecedensủ $k i$-típus visszaszorulása és a mely-, majd a $m i$-típus feljövetele - a könyvnyelvé a vezető szerep: DöMÖTÖR 2017.) Az előtagosság terjedésére vonatkozó összképet illetően a két regiszter igen hasonló képet mutat.

A három névmáspárt egyenként megnézve azonban a könyvnyelv innovatívabbnak bizonyul, mint az élőnyelvi regiszter. A $k i$ - és a $m i$-típus terjedésében a könyvnyelv vezet, a mely-típusban viszont a beszéltnyelv. Ez nem várt eltérés, és a vizsgálat jelen szintjén nem is adódik rá magyarázat. Feltehető azonban, hogy közelebb vihet a kérdés megválaszolásához az előtagos/előtag nélküli formák grammatikai szerkezetek szerinti vizsgálata. Várhatóan eredményt hozhat például a független vonatkozó mellékmondatok, illetve a vonatkozó névmást jelzőként szerepeltető szerkezetek tanulmányozása. Beszéltnyelvi (boszorkányperekből származó) adatokat kiragadva a jelenségek illusztrálására: független vonatkoztatás: ... kiáltás lött az házban az ágya alatt. Me ly szó is - hiti után úgy vallja a tanú - hogy nyilván Sallainéé volt. (TMK.); jelzői pozíció: A me ly lábravalóból madzagot Bíró Mihályné ellopta, azon lábravalót nem is lehetett az fátensnek viselni (TMK.).

Kimagaslik azonban az innovatív formák használatában a bibliafordítások nyelvezete: az előtagos formák elterjedtsége jelentősen megelózi mind az általános könyvnyelvet, mind az élőnyelvet. Ez a $k i \sim a(z) k i$ és a mely $\sim a(z)$ mely névmáspárokra külön-külön is igaz; a $m i \sim a(z) m i$ esetében az élőnyelvvel szembeni előnyröl lehet csak beszélni, hiszen ennek mutatója a könyvnyelvben is $100 \%$-hoz közeli volt. Vagyis a bibliafordítók mutatkoznak a leginkább arra hajlamosnak - ezúttal egy olyan jelenség esetében, amelyet nem befolyásolnak az elvszerüen követendő idegen nyelvi előzmények -, hogy a terjedőben lévő újítást felkarolják. Ez egyenként is vonatkozik az öt fordító legtöbb választására: a háromféle névmástípusra kapott 15 adatpár zömében, 11-ben az innovatív alakok gyakorisága mind a könyvnyelvi, mind az élőnyelvi eredményt megelözi (részletesen 1. DÖMÖTÖR 2020).

A bibliafordítások vezető szerepe - felerősítve, hogy a háromból két névmáspár esetében a könyvnyelv megelözi az élőnyelvet - arra vall, hogy a vizsgált jelenség tekintetében az igényesebb nyelvhasználat, a választékosabb stílus mutatkozik nyitottabbnak az újításra.

A terjedés további részleteiről, regiszterek közötti eltéréseiről a középmagyar kor későbbi korszakainak anyagára épülő vizsgálat adhat majd számot.

Kulcsszók: vonatkozó névmás, nyelvi váltakozás és változás, konzervatív és innovatív formák, történeti szociolingvisztika, nyelvi regiszterek, középmagyar kori élőnyelv. 


\section{Hivatkozott irodalom}

Aitchison, JEAN 1987. The Language lifegame: Prediction, Explanation and linguistic change. In: KoOPMAN, Willem F. - VAN DER LEEK, FrederiKe - Fischer, OlGA EATON, Roger eds., Explanation and Linguistic Change. John Benjamins, Amsterdam. 11-32. https://doi.org/10.1075/cilt.45.03ait

BENKÖ LORÁND 1988. A történeti nyelvtudomány alapjai. Tankönyvkiadó, Budapest.

BUDENZ JÓZSEF 1866. Szintén valami az a ki, a mi-ről. Nyelvészeti Közlemények 5: 19-36.

DÖMÖTÖR ADRIENNE 2008. A középmagyar kori minőségjelzői mellékmondatok (állományés változásvizsgálat). In: HAADER LEA - HORVÁTH LÁSZLÓ szerk., Tanulmányok a középmagyar kor mondattana köréböl. Segédkönyvek a nyelvészet tanulmányozásához 89. Tinta Könyvkiadó, Budapest. 23-39.

DÖMÖTÖR ADRIENNE 2017. „Oly napot végezni, ki bizonyos legyen”. A névmási kötőszó a középmagyar kor élönyelvében. In: FORGÁCS TAMÁS - NÉMETH MiKLÓS - SINKOVICS BALÁzS szerk., A nyelvtörténeti kutatások újabb eredményei IX. Szegedi Tudományegyetem Magyar Nyelvészeti Tanszék, Szeged. 39-53.

DÖMÖTÖR ADRIENNE 2020. Innovatív (előtagos) és konzervatív (előtag nélküli) vonatkozó névmásformák versengése a 16. századi nyomtatott bibliafordításokban. In: É. KISS KATAlin - Hegedüs AtTILA - PINTÉR Lilla szerk., Nyelvelmélet és diakrónia 4. PPKE BTK Elméleti Nyelvészeti Tanszék - Magyar Nyelvészeti Tanszék, Budapest-Piliscsaba. 47-67.

FAARLUnD, JAN TERJE 1990. Syntactic Change - Toward a Theory of Historical Syntax. Mouton de Gruyter, Berlin - New York.

HAADER LEA 1995. Az alárendelő mondatok. In: BENKÖ LORÁND föszerk., A magyar nyelv történeti nyelvtana II/2. A kései ómagyar kor. Mondattan. Szöveggrammatika. Akadémiai Kiadó, Budapest. 506-665.

HAADER LEA 1997. Mozaikok névmásokról és ómagyar kori használóikról. In: KISS GÁBOR - ZAICZ GÁBOR szerk., Szavak - nevek - szótárak. Írások Kiss Lajos 75. születésnapjára. MTA Nyelvtudományi Intézet, Budapest. 118-124.

HeINE, BERND - KUTEVA, TANIA 2002. World Lexicon of Grammaticalization. Cambridge University Press, Cambridge.

JOSEPH, BRIAN D. 2012. Lexical Diffusion and the Regular Transmission of Language Change in its Sociohistorical Context. In: HeRnANDEZ-CAMPOY, JUAN MANUEL Conde-Silvestre, JuAn CAMILO eds., The Handbook of Historical Sociolinguistics. Blackwell Publishing, Malden. [Blackwell Reference Online, 2013. április 30.] $218-226$.

JuHÁSz DEZsŐ 1991. A kötőszók. In: BENKÖ LORÁND föszerk., A magyar nyelv történeti nyelvtana I. A korai ómagyar kor és elözményei. Akadémiai Kiadó, Budapest. 476-500.

JUHÁSZ DEZSŐ 1992. A kötőszók. In: BENKÖ LORÁND föszerk., A magyar nyelv történeti nyelvtana II/1. A kései ómagyar kor. Morfematika. Akadémiai Kiadó, Budapest. $772-814$.

KÁROLY SÁNDOR 1980. Hozzászólás a „Történeti nyelvtanírásunk helyzete és feladatai” c. előadáshoz. In: IMRE SAMU - SZATMÁRI ISTVÁN - SzÜTS LÁSZLÓ szerk., A magyar 
nyelv grammatikája. A magyar nyelvészek III. nemzetközi kongresszusának elöadásai. Nyelvtudományi Értekezések 104. Akadémiai Kiadó, Budapest. 41-53.

KISS JENÖ 2003. Általános kérdések. In: KISS JENŐ - PUSZTAI FERENC szerk., Magyar nyelvtörténet. Osiris Kiadó, Budapest. 11-68.

Kroch, Anthony 1989. Reflexes of Grammar in Patterns of Language Change. Language Variation and Change 1: 199-244.

Kroch, Anthony 1994. Morphosyntactic Variation. In: BEALs, K. et al. eds., Papers from the 30th Regional Meeting of the Chicago Linguistics Society: Parasession on Variation and Linguistic Theory. ftp://babel.ling.upenn.edu/facpapers/tony_kroch/ papers/morphosyntax.pdf (2018. 07. 19.)

LEHMANN, CHRISTIAN 2004. Data in linguistics. The Linguistic Review 21: 175-210. http://www.christianlehmann.eu/publ/data_in_linguistics.pdf 1-40. (A hivatkozások ez utóbbi lapszámai alapján.) (2010. 01. 12.)

PINTZUK, SUSAN 2003. Variationist Approaches to Syntactic Change. In: JOSEPH, BRIAN D. - JANDA, RICHARD D. eds., The Handbook of Historical Linguistics. Blackwell Publishing, Malden. 509-527.

SIPOS PÁL 1991. A névmások. In: BENKÖ LORÁND föszerk., A magyar nyelv történeti nyelvtana I. A korai ómagyar kor és elözményei. Akadémiai Kiadó, Budapest. 353-400.

SZENCZI Molnár AlBert 1610. Novae Grammaticae Ungaricae. Hanau.

G. VARGA GYÖRGYI 1992. A névmások. In: BENKÖ LORÁND föszerk., A magyar nyelv történeti nyelvtana II/1. A kései ómagyar kor. Morfematika. Akadémiai Kiadó, Budapest. 455-569.

C. VLADÁR ZSUZSA fordítás, előszó, jegyzetek 2004. Szenczi Molnár Albert: Novae Grammaticae Ungaricae libri duo (1610). Új magyar grammatika két könyvben. A Magyar Nyelvtudományi Társaság Kiadványai 222. Magyar Nyelvtudományi Társaság, Budapest.

\section{Idézett ómagyar források}

Jókai-kódex (1372 u./1448 k.). Közzéteszi: P. BALÁzS JÁnOS. Akadémiai Kiadó, Budapest, 1981.

Müncheni kódex (1416 u./1466). Közzéteszi: NYÍRI ANTAL. Akadémiai Kiadó, Budapest, 1971.

Döbrentei-kódex (1508). Közzéteszi: ABAFFy Csilla - T. SzABó Csilla. Argumentum Kiadó - Magyar Nyelvtudományi Társaság, Budapest, 1995.

Jordánszky-kódex (1516-1519). Fakszimile kiadás. Helikon Kiadó, Budapest, 1984.

\section{Felhasznált nyomtatott források}

\section{Bibliafordítások: Márk-evangélium}

Félegyházi Tamás: Újtestamentum (1586). = Első kiadás, innen: http://oszkdk.oszk.hu/ storage/00/01/65/73/dd/1/RMK_I_0218_1_kicsi.pdf (2019. 06. 02.)

Heltai Gáspár (és tsai): Újtestamentum $(1561) .=\overline{A z} 1572$-es (második) kiadás, innen: https:// rmk.hungaricana.hu/hu/view/RMK_I_51/?pg=0\&layout=s (1562) (2019.06. 02.) 
Károlyi Gáspár: Szent Biblia (1590). = Hasonmás kiadás. Magyar Helikon, Budapest, 1981.

Pesthi Gábor: Újtestamentum (1536). = Hasonmás kiadás. Balassi Kiadó, 2002.

Sylvester János: Újtestamentum (1541). = Hasonmás kiadás. Akadémiai Kiadó, Budapest, 1960.

\section{Általános könyvnyelv}

Balassi Bálint: Szép magyar komédia (1558). = Balassi Kiadó, Budapest, 1999. Szöveggondozó: KöSZEGHY PÉTER és SzENTMÁRTONI SZABÓ GÉZA. A teljes szöveg.

Bornemisza Péter: Tragédia magyar nyelven az Szophoklész Élektrájából (1558). = Hasonmás kiadás. Balassi Kiadó, Budapest, 2009. A teljes szöveg.

Heltai Gáspár: Ponciánus császár históriája (1572). = Magyar Helikon, Budapest, 1976. Szöveggondozó: NEMESKÜRTY ISTVÁN. 1-15. novella.

Károlyi Gáspár: Két könyv minden országoknak és királyoknak jó és gonosz szerencséjeknek okairúl (1563). = Első kiadás, innen: https://mek.oszk.hu/03400/03469/ index.phtml\#. A teljes szöveg.

Pécsi Lukács: Szent Ágoston doktornak elmélkedő ... imádságai (1591). = Hasonmás kiadás. MTA Irodalomtudományi Intézete - MTA Könyvtára, Budapest, 1988. A szöveg első harmadrésze.

Pesthi Gábor: Ezópus fabulái (1536). = Hasonmás kiadás. Közoktatásügyi Kiadó, Budapest, 1950. A teljes szöveg.

Sylvester János: Újtestamentum (1541). = Hasonmás kiadás. Akadémiai Kiadó, Budapest, 1960. A prózában írt kiegészítő fejezetek teljes anyaga.

Telegdi Miklós: Felelet Bornemisza Péternek Fejtegetés nevü könyvére (1580). = Első kiadás, innen: http://oszkdk.oszk.hu/storage/00/00/07/88/dd/1/RMK_I_177.pdf. A szöveg első fele. (2019. 05. 06.)

\section{Felhasznált korpuszok}

TMK. = Történeti magánéleti korpusz. http://TMK.nytud.hu MNSZ. = Magyar nemzeti szövegtár. http://MNSZ.nytud.hu

\section{Competing relative pronouns with and without a prefix in the first half century of the Middle Hungarian era}

The competition between the forms of relative pronouns with and without a prefix is a process that has been going on from the Old Hungarian era up to the present day. The innovative variant emerged by reanalysis from sequences of a demonstrative pronoun and a relative pronoun. We can observe successive processes of grammaticalisation in the emergence of the Hungarian relative pronouns of today. The prefixed variant can be documented since Late Old Hungarian. The spread of forms with a prefix gathers momentum in the first decades of the Middle Hungarian era. The paper addresses the question of which register had the leading role in that development. Was it a kind of language use close to spoken living language, the primary terrain for initiating linguistic changes? Or did written language shaped by book printing let the innovation develop more readily? I studied 
the behaviour of the pairs $k i \sim a(z) k i$ 'who', mi a(z)mi 'that', and mely $\sim a(z) m e l y$ 'which' on a sample of about 4000 data points. I demonstrate the findings by means of diagrams showing percentage distribution. I also tested the significance of the statements on the size of deviations. In addition, I also touch upon general questions on the spread of linguistic change. A major result of the paper is that in the case of two out of the three pairs of pronouns book language has priority over spoken language. However, the idiom of Bible translations holds the first place over both registers. Thus, it can be claimed that more sophisticated language use and polished style appear to be more open to innovation with respect to the phenomenon examined.

Keywords: relative pronoun, linguistic variation and change, conservative and innovative forms, historical sociolinguistics, linguistic registers, spoken living language of Middle Hungarian.

DÖMÖTÖR ADRIENNE MTA Nyelvtudományi Intézet 